\title{
Multiple Symmetric Lipomatosis
}

\author{
A DEFECT IN ADRENERGIC-STIMULATED LIPOLYSIS
}

\author{
Giuliano Enzi, Emine M. Inelmen, and Aldo Baritussio, Department of \\ Internal Medicine, Division of Gerontology and Metabolic Diseases, \\ University of Padua, Italy \\ PaOla Dorigo and Marco Prosdocimi, Department of Pharmacology, \\ University of Padua, Italy \\ Francesco Mazzoleni, Division of Plastic Surgery, University of \\ Padua, Italy
}

A B S T R A C T The cellularity of normal and lipomatous adipose tissue and its response to different lipolytic agents have been studied in a group of 10 patients with multiple symmetric lipomatosis (MSL).

In MSL patients, fat cells from lipomatous tissue are smaller than normal, uninvolved adipocytes. Fat cells from lipomata show minimal variations in size following conspicuous increase of lipomatous masses. These findings suggest that the growth of lipomata can be attributed to the neoformation of adipocytes rather than to an enlargement in the single fat cells.

The incidence of reduced glucose tolerance and of hyperlipoproteinemia is similar in MSL patients and in controls. A significant reduction in plasma free fatty acids was observed in MSL patients after a 24-h fast as well as after noradrenaline infusion.

A specific insensitivity of lipomatous tissue to the lipolytic effect of noradrenaline and isoprenaline was observed in vitro, as indicated by glycerol release in the medium, whereas response to theophylline and to dibutyryl cyclic AMP was retained. The lipolytic response to catecholamines was normal in the nonlipomatous adipose tissue of MSL patients. In basal conditions ATP concentrations were similar in normal and in lipomatous adipose tissue. However, incubation with noradrenaline induced a significant fall in intracellular ATP levels in normal tissue, whereas no variations were observed in lipomatous tissue. Theophylline, instead, induced a prompt and significant decrease in intracellular ATP levels in lipomatous tissue. These obervations indicate that the block in catechol-

Preliminary results of in vitro studies were presented at the 4th International Congress of Endocrinology, Hamburg, Germany 18-24 July 1976. (Abstr. 534.)

Received for publication 1 November 1976 and in revised form 1 July 1977. amine-stimulated lipolysis in lipomatous tissue of MSL patients can be localized at a level preceding the formation of cyclic AMP.

\section{INTRODUCTION}

Multiple symmetric lipomatosis (MSL) ${ }^{1}$ or LaunoisBensaude lipomatosis $(1,2)$ is a disease characterized by the formation of nonencapsulated lipomas, situated symmetrically at the neck, the nape of the neck, the shoulders, the supraclavicular and deltoid region, the abdomen, groin, and buttocks (3-8). The lesion most likely originates in the subcutaneous adipose tissue, subsequently penetrating between the muscular fascia or in the spaces between organs, apparently following the path of least resistance. Although this disease is usually asymptomatic, it may cause severe complications due to tracheal, laryngeal, and mediastinal compression (9-13). Moreover, spontaneous regression of lipomatous masses has been described (14).

The pathogenesis of MSL is unknown. Alcoholism, with more or less severe hepatic involvement (9, 14-17), has been reported. Association of reduced glucose tolerance and hyperinsulinemia $(5,18-21)$, hyperlipoproteinemia $(5,15,18)$, hyperuricemia $(5,10$, $15,19-21$ ), and renal tubular acidosis (19) has also been described.

In vitro studies evaluating lipolysis or lipid synthesis in lipomatous adipose tissue have not been reported in literature.

The purpose of our investigation was to study the cell size of lipomatous and normal adipose tissue of 10 MSL patients and the cells variation following increase in lipomatous masses or in total body fat. In

\footnotetext{
${ }^{1}$ Abbreviation used in this paper: MSL, multiple symmetric lipomatosis.
} 
addition, some aspects of in vivo and in vitro lipolysis were studied to identify possible specific metabolic alterations in both lipomatous and normal tissue in these patients.

\section{METHODS}

10 males affected with MSL, ranging in age from 26 to $57 \mathrm{yr}$, were studied. Volume and extension of lipomata varied and in some cases only the nap of the neck and the shoulders presented round, distinct masses $\cong 6-8 \mathrm{~cm}$ in diameter (Fig. 1). In others, there was a symmetric involvement extending to the deltoid region, the anterior wall of the chest, the abdomen, and the groin. The $10 \mathrm{MSL}$ patients and a control group of 10 healthy subjects, matched for age, underwent the following tests:

Inhibition of lipolysis by oral glucose loading. $100 \mathrm{~g}$ of glucose diluted in $200 \mathrm{ml}$ of water was administered. Venous blood samples were collected at $0,30,60,90$, and $180 \mathrm{~min}$ for determination of free fatty acids (FFA), blood glucose, and plasma immunoreactive insulin. Glucose was determined enzymatically, insulin by radioimmunoassay (22), and FFA by the titrimetric method (23).

Inhibition of lipolysis by insulin. $0.1 \mathrm{U}$ of glucagon-free insulin/kg body weight was rapidly injected i.v. Venous blood samples were taken at $0,20,40,60,90$, and $120 \mathrm{~min}$ for plasma FFA and blood glucose determinations.

FFA mobilization during a 24- $h$ fast. Fasting was begun at 7 p.m. and samples for plasma and glucose determinations were collected at 9 a.m., and 1, and 7 p.m. of the following day. Patients and controls were instructed to maintain absolute rest during the fast and allowed water ad lib.

Noradrenaline-induced FFA mobilization. $150 \mu \mathrm{g}$ of noradrenaline bitartrate, diluted in $100 \mathrm{ml}$ of saline, was administered i.v. over $20 \mathrm{~min}$. Venous blood samples were collected at $0,20,30,40,60,90$, and $120 \mathrm{~min}$ for plasma FFA determinations.

Fat cell sizing. Determination of adipose cell size was carried out according to the method of Sjöström et al. (24). Tissue fragments were obtained either by percutaneous needle biopsy or by surgical biopsy from central zones of the lipomata and adjacent, uninvolved areas. In the control group, adipose tissue biopsies were always carried out at the gluteal region. In three patients, biopsy of normal and pathological adipose tissue was repeated following conspicuous weight loss achieved by means of 800-cal diets. In one patient, biopsy was repeated following a marked increase in the volume of the lipomatous masses. Body fat mass was calculated according to the formula of Edwards and White (25). Lipoprotein electrophoresis was carried out on agarose gel (26) and typing of hyperlipoproteinemia was made according to Fredrickson's and Lees' classification (27).

In vitro study of lipolysis. Surgical biopsies of lipomatous and normal subcutaneous adipose tissue were obtained from five patients under local anesthesia with Xylocaine (Astra, Södertälije, Sweden). Normal adipose tissue was taken from uninvolved regions as close as possible to the lipomatous masses. The fragments were placed in saline at $20-25^{\circ} \mathrm{C}$ and immediately transferred to the laboratory. Tissue slices weighing 100 $\pm 5 \mathrm{mg}$ were placed in $1.9 \mathrm{ml}$ of Krebs-Ringer bicarbonate solution, pH 7.2, containing 3.5\% bovine albumin. After preliminary incubation in a metabolic shaker at $37^{\circ} \mathrm{C}$ for $30 \mathrm{~min}$, lipolytic agents (noradrenaline, $10 \mu \mathrm{M}$; isoprenaline, $10 \mu \mathrm{M}$; dibutyryl cyclic AMP, $10 \mathrm{mM} ; 10 \mathrm{mM}$, and theophylline $3 \mathrm{mM}$ were added.

In order to study the time-course of lipolysis in lipomatous adipose tissue, a parallel incubation experiment with nor-

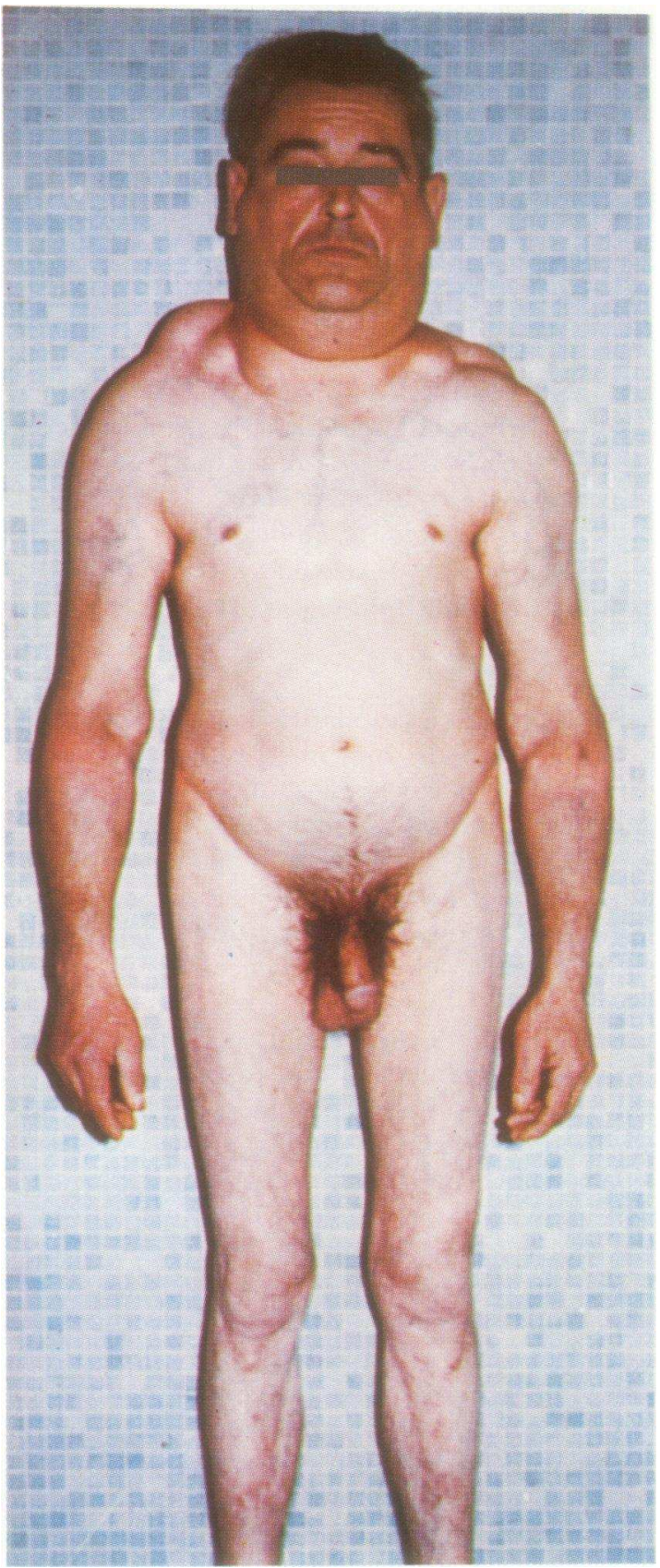

FIGURE 1 Typical aspect of a patient with MSL. Lipomata appear as round, circumscribed masses in the supraclavear region and at the neck. Lipomatous masses have spread to the chin to form a Madelung collar. Signs of mediastinal compression are present.

adrenaline or theophylline was also carried out. In the latter experiment, incubation was halted at $30,40,90$, and 150 min by adding $0.1 \mathrm{ml} 2.5 \mathrm{~N} \mathrm{H}_{2} \mathrm{SO}_{4}$ to each assay. Due to the insufficient amount of fat samples, this study was not carried out on normal subcutaneous adipose tissue.

At the end of the incubation periods, tissues were immediately separated from the medium by vacuum filtration and 
then homogenized in $2 \mathrm{ml}$ of distilled water in a PotterElvehjem homogenizer. The homogenate was directly transferred to the extraction mixture for FFA and glycerol determination. FFA in the medium and in the tissue and glycerol in the medium were titrated according to the methods of Dole (23) and Korn (28), respectively, and expressed as microequivalents FFA or micromoles glycerol per gram of fresh tissue.

ATP determination in adipose tissue. ATP extraction was performed according to the Bihler and Jeanrenaud method (29) with the following modifications. After filtration under vacuum, fat samples were immediately transferred into vials

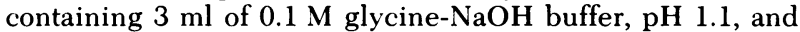
heated to $95^{\circ} \mathrm{C}$ in a water bath. The samples were incubated at $95^{\circ} \mathrm{C}$ for $15 \mathrm{~min}$ with occasional shaking, cooled, and then centrifuged at $0^{\circ} \mathrm{C}$ for $7 \mathrm{~min}$ at $7,000 \mathrm{rpm}$. The supernate was removed by suction and transferred into cooled, graduated vials for ATP determination. The overall recovery of the synthetic nucleotide added to the control samples was between 80 and $95 \%$. In each experiment, data was corrected for recovery.

The ATP content of alkaline glycine extracts was determined by the luciferin-luciferase method of Strehler and Trotter $(30,31)$, as adapted by Bihler and Jeanrenaud (29).

The enzyme solution was obtained by dissolving a commercial firefly tail extract in $0.33 \mathrm{M}$ arsenate buffer, $\mathrm{pH} 7.4$, containing $0.02 \mathrm{M} \mathrm{MgSO}_{4}$. The concentration of the enzyme was $0.15 \mathrm{mg}$ dry extract $/ \mathrm{ml}$ which, in our experimental conditions, gave a linear relation of counts/minutes to ATP concentrations between 0.25 and $5.0 \mathrm{nmol} / \mathrm{vial}$.

The very high initial activity of the enzyme solution declined rapidly during the 1 st $h$ and then remained quite stable for several hours. For this reason fresh enzyme solutions were prepared daily, kept at $4^{\circ} \mathrm{C}$ and then used 90 min later.

All results have been expressed as nanomole ATP per gram of fresh tissue. Statistical analysis was done by Student's $t$ test.

\section{RESULTS}

The average overweight of our MSL patients ranged from -12.7 to $+37.2 \%$ of their ideal body weight (Table I). All the patients presented very reduced development of normal subcutaneous adipose tissue. Average thickness of the cutaneous fold in the middle anterior region of the thigh was $6.8 \pm 0.7 \mathrm{~mm}$, this was significantly less than that of control subjects matched for age $(9.4 \pm 0.5 \mathrm{~mm} ; P<0.01)$. It appears that body fat excess in MSL patients is due exclusively to the presence of lipomatous masses, even if it is not technically possible to evaluate the weight of normal and lipomatous tissue separately.

Fat cell sizing. Average weight of the adipocytes from lipomata, expressed as microgram of triglyceride per cell $(0.49 \pm 0.07 \mu \mathrm{g})$, was not significantly lower than that of normal uninvolved adipocytes $(0.65 \pm 0.08$ $\mu \mathrm{g})$. Average adipocyte weight in controls $(0.68$ $\pm 0.09 \mu \mathrm{g}$ ) was not significantly different from the value observed in the normal adipose tissue of MSL patients (Table I).

The three patients whose adipose mass decreased by $32.9,17.2$, and $37.2 \%$ after a hypocaloric diet, had a correlated reduction in normal adipocyte weight of $37.0,16.6$, and $39.0 \%$, respectively. Reduction in lipomatous adipocyte weight, however, was constantly lower $(20.4,10.5$, and $27.3 \%$, respectively) (Table II).

The patient with an observed increase of the lipomatous masses had the average weight of the adipocytes vary from $0.45 \pm 0.6$ to $46 \pm 0.6 \mu \mathrm{g}$ (Table II). The

TABLE I

Anthropometric and Metabolic Parameters and Fat Cell Weight of Normal and Lipomatous Adipose Tissue in MSL Patients

\begin{tabular}{|c|c|c|c|c|c|c|c|c|c|c|c|c|}
\hline \multirow[b]{2}{*}{ Patient } & \multirow[b]{2}{*}{ Age } & \multirow{2}{*}{$\begin{array}{c}\text { Body } \\
\text { wt. }\end{array}$} & \multirow[b]{2}{*}{ Height } & \multirow{2}{*}{$\begin{array}{c}\text { Ideal } \\
\text { body } \\
\text { wt. }\end{array}$} & \multirow{2}{*}{$\begin{array}{l}\text { Over- } \\
\text { weight }\end{array}$} & \multirow{2}{*}{$\begin{array}{l}\text { Body } \\
\text { fat } \\
\text { mass }\end{array}$} & \multicolumn{2}{|c|}{ Fat cell wt.* } & \multirow[b]{2}{*}{ Cholesterol } & \multirow[b]{2}{*}{ Triglycerides } & \multirow{2}{*}{$\begin{array}{c}\text { Lipo- } \\
\text { protein } \\
\text { pattern }\end{array}$} & \multirow[b]{2}{*}{ Uric acid } \\
\hline & & & & & & & $N$ & $\mathrm{~L}$ & & & & \\
\hline & $y r$ & $k g$ & $\mathrm{~cm}$ & $\mathrm{~kg}$ & $\%$ & $k g$ & $\mu g$ & $\mu g$ & $m g / 100 \mathrm{ml}$ & $m g / 100 \mathrm{ml}$ & & $\mathrm{mg} / 100 \mathrm{ml}$ \\
\hline C. B. & 39 & 81.8 & 176 & 72.8 & 11.0 & 23.3 & 0.59 & 0.32 & 205 & 110 & Normal & 4.60 \\
\hline C. $\mathrm{O}$. & 49 & 74.5 & 168 & 65.1 & 12.6 & 23.1 & 0.53 & 0.38 & 215 & 125 & Normal & 5.10 \\
\hline C. S. & 57 & 81.5 & 169 & 65.8 & 19.3 & 27.3 & - & 0.23 & 170 & 140 & Normal & 4.70 \\
\hline I. A. & 32 & 60.3 & 170 & 66.3 & -10.0 & 13.0 & 0.66 & 0.60 & 188 & 110 & Normal & 5.00 \\
\hline M. G. & 43 & 51.6 & 160 & 58.2 & -12.7 & 12.1 & - & 0.40 & 170 & 93 & Normal & 3.30 \\
\hline P. D. & 56 & 74.0 & 175 & 72.0 & 2.7 & 18.6 & 0.41 & 0.46 & 273 & 285 & II B & 6.60 \\
\hline S. G. & 56 & 77.4 & 172 & 68.3 & 11.8 & 24.1 & 1.08 & 0.98 & 190 & 108 & Normal & 8.20 \\
\hline T. R. & 49 & 92.5 & 171 & 67.4 & 37.2 & 33.6 & 0.84 & 0.76 & 171 & 155 & Normal & 8.20 \\
\hline V. A. & 41 & 67.7 & 169 & 65.8 & 2.8 & 18.2 & 0.47 & 0.33 & 232 & 98 & Normal & 5.00 \\
\hline Z. A. & 26 & 60.0 & 163 & 60.2 & -0.3 & 14.5 & 0.59 & 0.44 & 302 & 120 & II A & 4.10 \\
\hline$\overline{\mathrm{m}} \pm \mathrm{SEM}$ & $\begin{array}{r}45.4 \\
\pm 3.4\end{array}$ & $\begin{array}{r}72.1 \\
\pm 3.9\end{array}$ & $\begin{array}{l}169 \\
\pm 1.5\end{array}$ & $\begin{array}{r}66.2 \\
\pm 1.4\end{array}$ & $\begin{array}{r}6.4 \\
\pm 3.9\end{array}$ & $\begin{array}{r}20.8 \\
\pm 2.2\end{array}$ & $\begin{array}{r}0.65 \\
\pm 0.08\end{array}$ & $\begin{array}{r}0.49 \\
\pm 0.07\end{array}$ & $\begin{array}{l}212 \\
\pm 14.4\end{array}$ & $\begin{array}{r}134 \\
\pm 18\end{array}$ & & $\begin{array}{l}\quad 5.48 \\
\pm 0.5\end{array}$ \\
\hline $\begin{array}{l}\text { Controls } \\
\overline{\mathrm{m}} \pm \text { SEM }\end{array}$ & $\begin{array}{r}43.2 \\
\pm 2.4\end{array}$ & $\begin{array}{r}74.2 \\
\pm 4.5\end{array}$ & $\begin{array}{l}168 \\
\pm 1.6\end{array}$ & $\begin{array}{r}66.0 \\
\pm 1.2\end{array}$ & $\begin{array}{r}8.4 \\
\pm 4.2\end{array}$ & $\begin{array}{r}23.5 \\
\pm 2.5\end{array}$ & $\begin{array}{r}0.68 \\
\pm 0.08\end{array}$ & - & $\begin{array}{r}204 \\
\pm 31\end{array}$ & $\begin{array}{r}117 \\
\pm 23\end{array}$ & & $\begin{array}{l}5.28 \\
\pm 0.7\end{array}$ \\
\hline
\end{tabular}

* $\mathrm{N}$, normal subcutaneous adipose tissue; $\mathrm{L}$, lipomatous adipose tissue. 
TABLE II

Variation in Fat Cell Weight of Lipomatous and Normal Adipose Tissue in MSL Patients after Reduction in Body Fat Mass (S. G., T. R., Z. L.) and after Increase in Lipomatous Masses (P. D.)

\begin{tabular}{|c|c|c|c|c|c|c|c|c|}
\hline \multirow[b]{2}{*}{ Patient } & \multirow[b]{2}{*}{ Body wt. } & \multirow[b]{2}{*}{ Overweight } & \multirow[b]{2}{*}{ Fat mass } & \multicolumn{2}{|c|}{ Fat cell wt. } & \multirow{2}{*}{$\begin{array}{l}\text { Variation } \\
\text { of fat mass }\end{array}$} & \multicolumn{2}{|c|}{$\begin{array}{l}\text { Variation of } \\
\text { fat cell wt.* }\end{array}$} \\
\hline & & & & $\mathbf{N}$ & $\mathbf{L}$ & & $\mathbf{N}$ & L \\
\hline & kg & $\%$ & $k g$ & \multicolumn{2}{|c|}{$\mu g$} & $\%$ & \multicolumn{2}{|c|}{$\%$} \\
\hline S. G. & & & & & & & & \\
\hline Before & 77.4 & +11.8 & 24.1 & 1.08 & 0.98 & & & \\
\hline After & 67.0 & -1.9 & 16.2 & 0.68 & 0.78 & -32.9 & -37.0 & -20.4 \\
\hline \multicolumn{9}{|l|}{ T. R. } \\
\hline Before & 92.5 & +37.2 & 33.6 & 0.84 & 0.76 & & & \\
\hline After & 85.0 & +26.1 & 27.8 & 0.70 & 0.68 & -17.2 & -16.6 & -10.5 \\
\hline \multicolumn{9}{|l|}{ Z. L. } \\
\hline Before & 60.0 & +0.2 & 14.5 & 0.59 & 0.44 & & & \\
\hline After & 52.3 & -13.3 & 9.1 & 0.36 & 0.32 & -37.2 & -39.0 & -27.3 \\
\hline \multicolumn{9}{|l|}{ P. D. } \\
\hline Before & 74.0 & +2.7 & 18.7 & 0.41 & 0.45 & & & \\
\hline After & 78.1 & +8.5 & 21.4 & 0.40 & 0.46 & +14.4 & -2.4 & +2.1 \\
\hline
\end{tabular}

* N, normal subcutaneous adipose tissue; L, lipomatous adipose tissue.

slight increase in the volume of the single adipocytes does not, therefore, justify the marked increase observed in the lipomatous masses.

Inhibition of lipolysis during oral glucose tolerance
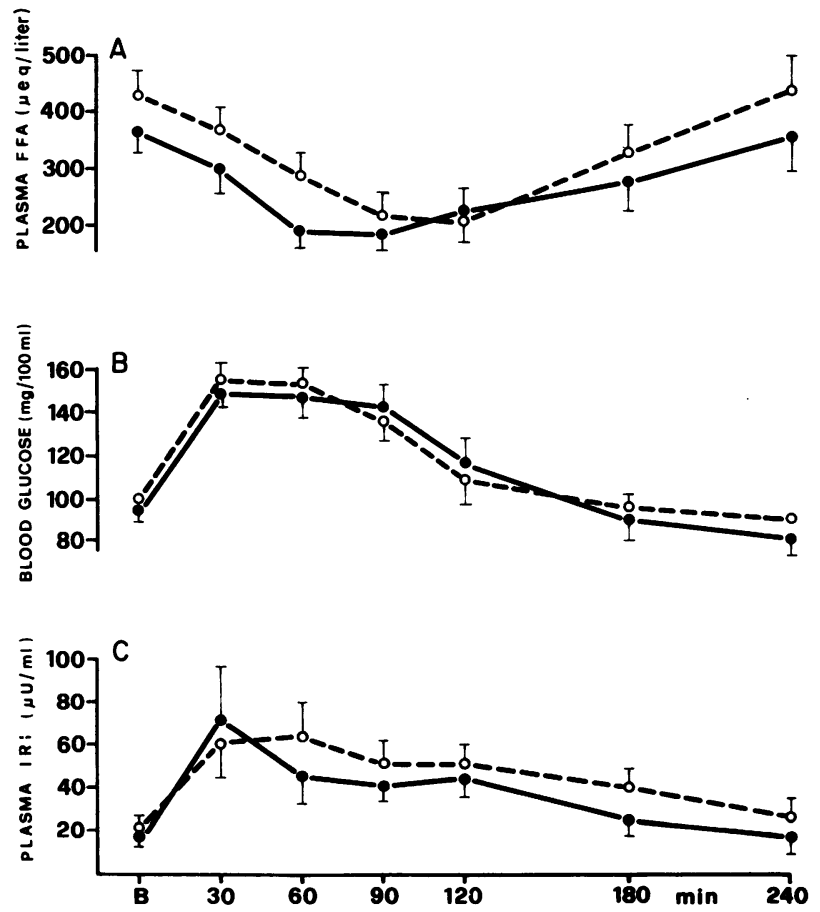

Figure 2 Variations in plasma FFA (A), blood glucose (B), and plasma immunoreactive insulin (IRI) (C) values after oral glucose load in MSL patients $(O)$ and in controls $(O)$ (SE of the mean is shown by the vertical bars). test and insulin sensitivity test. No significant differences were found between plasma FFA decrease after glucose loading (Fig. 2) and after insulin injection (Fig. 3) in MSL patients and in controls, even if constantly lower FFA values were observed in the former. Blood glucose and plasma immunoreactive insulin be-
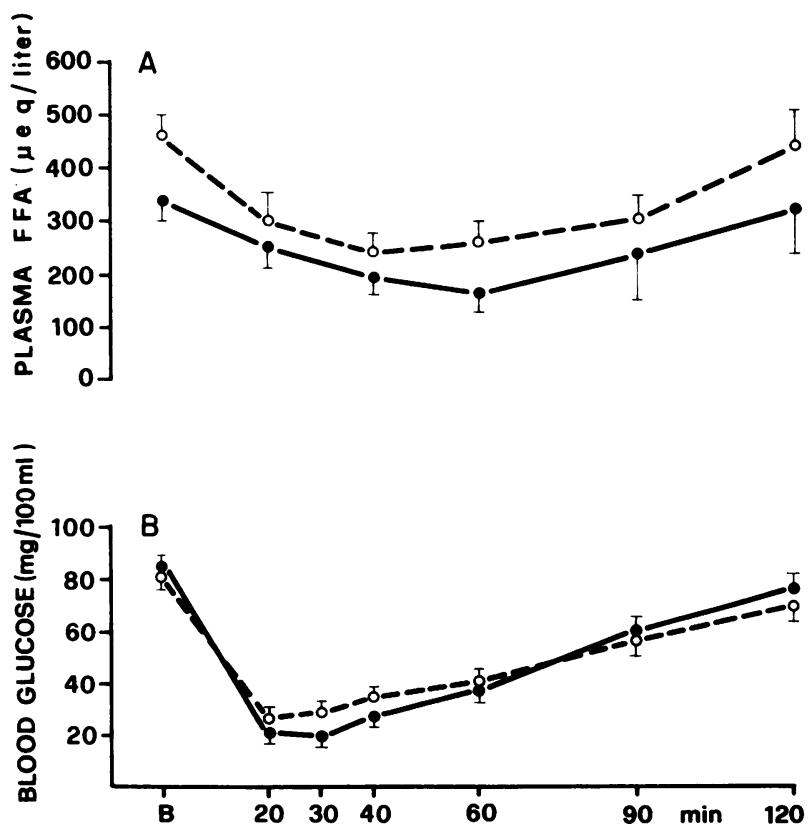

FIGURE 3 Variations in plasma FFA (A) and blood glucose (B) values after i.v. injection of insulin in MSL patients (O) and in controls (O). (SE of the mean is shown by the vertical bars). 

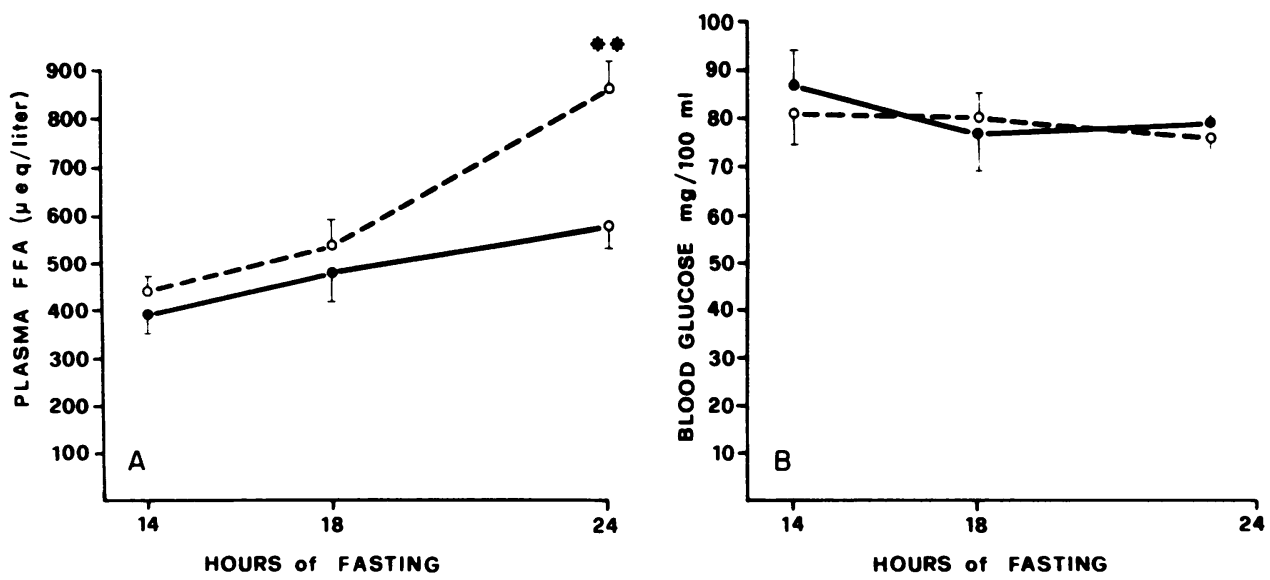

FIGURE 4 Variations in plasma FFA (A) and blood glucose (B) values during a 24-h fast in MSL patients (O) and in controls (O). ( $\mathrm{SE}$ of the mean is shown by the vertical bars) $* * P<0.05$.

havior was similar in MSL patients and in the controls (Figs. 2, 3).

Fasting lipolysis. Average FFA values after an overnight fast were lower in MSL patients as compared to the controls, but the difference was not statistically significant (Fig. 4). During fasting a smaller increase in plasma FFA levels was observed in MSL patients. After a 24-h fast, plasma FFA values in MSL patients were significantly lower than those of the controls $(P<0.05)$. Average glucose values during fasting were not significantly different in MSL patients than in the controls (Fig. 4).

Noradrenaline-induced FFA mobilization. Noradrenaline-induced FFA mobilization in MSL patients was also reduced. Mean FFA values were significantly lower at 30 and $60 \mathrm{~min}$ in MSL patients, when compared to those of the controls (Fig. 5).

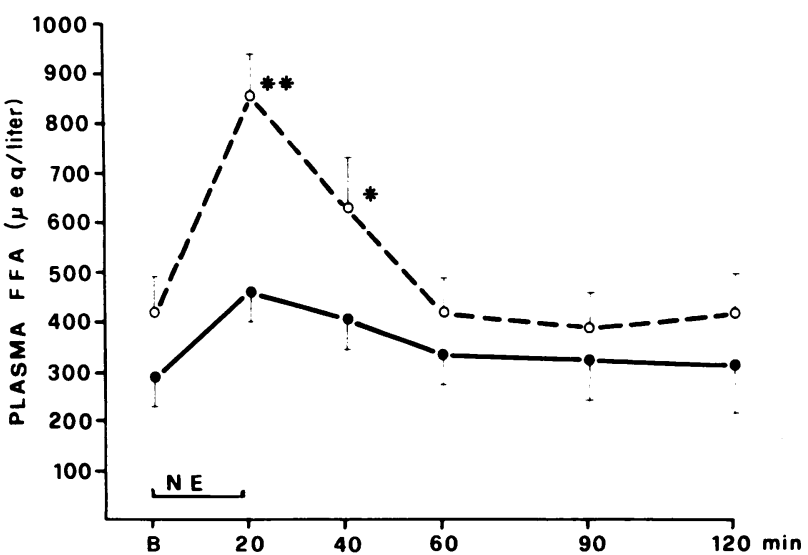

Figure 5 Variations in plasma FFA values after noradrenaline infusion (NE) in MSL patients (O) and in controls (O) (SE of the mean is shown by the vertical bars) $* 0.05$ $<P<0.1$; ** $P<0.05$
Time-course of FFA and glycerol release induced by noradrenaline and theophylline in lipomatous adipose tissue incubated in vitro. A defect in the noradrenaline-stimulated lipolysis was observed in lipomatous tissue, while theophylline induced a net lipolytic effect. In fact, glycerol levels in the medium increased progressively in the presence of theophylline but were unchanged in the presence of noradrenaline (Fig. 6).

Lipolytic effect of isoprenaline, dibutyryl cyclic AMP and theophylline on lipomatous and normal adipose tissue incubated in vitro. Basal lipolytic ac-

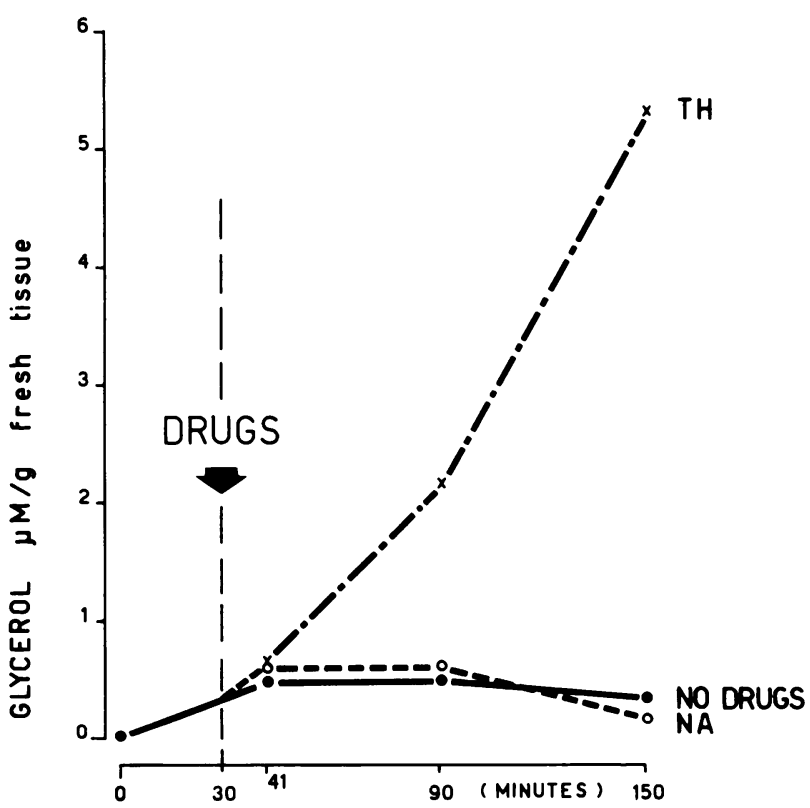

Figure 6 Effect of $10 \mu \mathrm{M}$ noradrenaline (NA) and of $3 \mathrm{mM}$ theophylline $(\mathrm{TH})$ on glycerol release in lipomatous adipose tissue. 
TABLE III

Effect of Different Lipolytic Agents on FFA and Glycerol Release in Subcutaneous and Lipomatous Adipose Tissue

\begin{tabular}{|c|c|c|c|c|c|c|}
\hline \multirow[b]{2}{*}{ Drugs in the medium } & \multicolumn{3}{|c|}{ FFA (Medium plus tissue) } & \multicolumn{3}{|c|}{ Glycerol in the medium } \\
\hline & $\mathbf{N}$ & $\mathbf{L}$ & & $\mathrm{N}$ & L & \\
\hline & \multicolumn{3}{|c|}{$\mu e q / g$ fresh tissue $180 \mathrm{~min}$} & \multicolumn{3}{|c|}{$\mu M /$ fresh tissue/180 min } \\
\hline - & $3.63 \pm 0.87$ & $3.43 \pm 0.92$ & & $1.43 \pm 0.23$ & $1.43 \pm 0.41$ & \\
\hline Noradrenaline $10 \mu \mathrm{M}$ & $6.77 \pm 0.28$ & $5.40 \pm 0.61$ & NS & $2.53 \pm 0.55$ & $1.25 \pm 0.12$ & $P<0.05$ \\
\hline Isoprenaline $10 \mu \mathrm{M}$ & $10.77 \pm 1.09$ & $3.28 \pm 1.25$ & $P<0.001$ & $3.14 \pm 0.14$ & $1.15 \pm 0.09$ & $P<0.001$ \\
\hline db-cAMP $1 \mathrm{mM}$ & $12.53 \pm 1.64$ & $17.27 \pm 0.48$ & $P<0.02$ & $4.62 \pm 0.64$ & $6.83 \pm 0.70$ & $P<0.05$ \\
\hline db-cAMP $10 \mathrm{mM}$ & $21.76 \pm 2.70$ & $27.34 \pm 1.43$ & $P<0.01$ & $7.98 \pm 0.69$ & $7.26 \pm 0.53$ & NS \\
\hline Theophylline $3 \mathrm{mM}$ & $17.14 \pm 3.10$ & $24.96 \pm 1.07$ & $P<0.01$ & $5.56 \pm 0.42$ & $6.75 \pm 0.87$ & NS \\
\hline
\end{tabular}

Each value represents the mean $( \pm S E M)$ of 3 to 10 assays from five experiments.

$P$ values were determined vs. normal subcutaneous adipose tissue.

tivity was similar in normal and lipomatous adipose tissue of MSL patients. The addition of lipolytic agents demonstrated that lipomatous tissue is insensitive not only to noradrenaline but even to the lipolytic action of $10 \mu \mathrm{M}$ isoprenaline. $10 \mathrm{mM}$ and $1 \mathrm{mM}$ dibutyryl cyclic AMP and $3 \mathrm{mM}$ theophylline, on the other hand, retained their lipolytic effect (Table III). In contrast to lipomatous tissue, the lipolytic response to $10 \mu \mathrm{M}$ noradrenaline and $10 \mu \mathrm{M}$ isoprenaline as well as to $3 \mathrm{mM}$ theophylline and $10 \mathrm{mM}$ and $1 \mathrm{mM}$ dibutyryl cyclic AMP was present in normal subcutaneous fat.

Effect of noradrenaline on ATP levels in lipomatous and in normal subcutaneous adipose tissue incubated in vitro. Due to limited subcutaneous adipose tissue availability, the effect of $10 \mu \mathrm{M}$ noradrenaline on intracellular ATP levels in normal adipose tissue was determined only at the end of the incubation period. Basal ATP levels were similar in normal and in lipomatous tissue. However, noradrenaline induced a significant reduction $(P<0.001)$ in intracellular ATP content only in normal tissue (Table IV).

Time-course of intracellular ATP variations induced

TABLE IV

Effect of Noradrenaline on ATP Levels in Lipomatous Adipose Tissue and in Normal Subcutaneous Adipose Tissue

\begin{tabular}{ccc}
\hline Drug in the medium & $\mathrm{L}$ & $\mathrm{N}$ \\
\hline & nmol ATP/g fresh tissue $150 \mathrm{~min}$ \\
- & $54.37 \pm 1.03$ & $57.77 \pm 0.58$ \\
Noradrenaline $10 \mu \mathrm{M}$ & $47.12 \pm 2.44^{*}$ & $33.90 \pm 0.52 \ddagger$ \\
\hline
\end{tabular}

* $\ddagger$ Statistical analysis with Student's $t$ test: ${ }^{*} P$ NS $\ddagger P<0.001$. $P$ values were determined vs. respective controls (assay without drugs). by noradrenaline and theophylline in lipomatous adipose tissue incubated in vitro. In the absence of lipolytic agents (control samples), intracellular ATP levels did not vary during the incubation period (Fig. 7). ATP concentrations in lipomatous tissue did not vary even after the addition of $10 \mu \mathrm{M}$ noradrenaline. Theophylline $3 \mathrm{mM}$, instead, induced a rapid, highly significant reduction $(P<0.001)$ in intracellular nucleotide levels. At the end of incubation, ATP levels were $40 \%$ lower than those of the control samples.

\section{DISCUSSION}

The etiology and pathogenesis of MSL is unknown. Most reports indicate that MSL is associated with alcoholism, reduced glucose tolerance, dyslipidemia, hyperuricemia, or gout. However, the disparity and

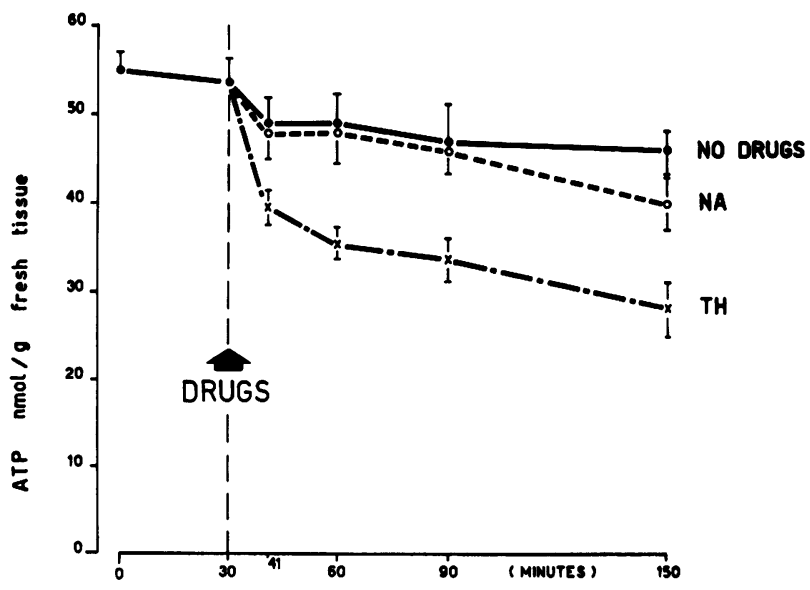

FIGURE 7 Effect of $10 \mu \mathrm{M}$ noradrenaline (NA) and $3 \mathrm{mM}$ theophylline (TH) on intracellular ATP levels in lipomatous adipose tissue. 
inconstancy of these associations with MSL seem to negate a causal relationship. In our 10 patients, the incidence of reduced glucose tolerance or of hyperlipemia is similar to that observed in the presumably healthy control group. It would seem, therefore, that MSL is a primary, specific disease of adipose tissue.

Lipomatous adipose cells are smaller in volume than normal adipocytes. At the same time, an increase in lipomatous masses takes place without a corresponding enlargement in the volume of the adipocytes. These observations suggest that lipomatous masses form and grow by a hyperplastic mechanism. In the adult, adipose tissue is of a definitive nature. Cellular proliferation, therefore, takes place by means of a neoplastic-like cell multiplication, or through a differentiation of preexisting cells.

In has been hypothesized that lipomatous masses form as a result of triglyceride accumulation in embryonal residues of brown adipose tissue (32). This would justify the existence of preferred sites of lipomata appearance, as well as their symmetrical arrangement but does not explain the diffusion of lipomas to other body regions. Recent studies suggested the existence of small lipid-deficient cells in adipose tissue (preadipocytes or adipoblasts) not distinguishable histologically from supporting cells. These cells are capable of triglyceride synthesis and consequently of differentiating into mature adipocytes (33). The formation of lipomatous masses could take place through a zonal differentiation of adipoblasts into mature adipocytes. A regression of these neoformed adipocytes could explain the remission of the lipomatous masses (14).

It is known that adrenergic denervation of adipose tissue produces cellular hypertrophy due to triglyceride accumulation (34). The reduced response to fasting and i.v. noradrenaline in MSL patients may indicate a "functional denervation" of some cellular populations. From this point of view, the in vitro study of the lipolytic process in adipose tissue of MSL patients assumes particular interest. In lipomatous tissue, basal lipolysis values do not differ from those of normal tissue, whereas lipolytic response to catecholamines is almost completely lacking. Lipomatous tissue is, however, highly sensitive to theophylline and dibutyryl cyclic AMP. Unlike lipomatous tissue, normal subcutaneous tissue from MSL patients responds to all the lipolytic agents studied. The response of normal adipose tissue from MSL patients to the lipolytic agents is similar to that observed in normal subjects (35-43).

Noradrenaline's inability to induce lipolysis in lipomatous tissue is further confirmed by the time-course of glycerol release (Fig. 6). Theophylline, instead, exerts a net lipid-mobilizing effect. These results emphasize the complete inertia of lipomatous tissue to the $\beta$ - adrenergic stimulation and agree with the observation of reduced lipolysis by noradrenaline observed in vivo.

To clarify the reasons for the lack of lipolytic response to catecholamines in lipomatous tissue, intracellular ATP concentrations, both in lipomatous as well as in normal tissue, were studied. The lipolytic process requires a continuous supply of energy, furnished by ATP. A correlation was, in fact, found between the rate of lipolysis and the fall in ATP concentrations $(44,45)$. Under basal conditions, intracellular ATP levels are similar in normal and lipomatous adipose tissue of MSL patients. No significant variations in intracellular ATP levels in lipomatous tissue occur when noradrenaline is added, whereas theophylline induces a progressive and significant decrease in nucleotide levels. The lack of a catecholamine effect is more evident when ATP levels in lipomatous and in normal adipose tissue are compared (Table IV).

These observations indicate that the metabolic alterations can be localized at a level preceding the formation of the cyclic nucleotide. However, it is not possible to establish whether this alteration is due to a specific modification in the $\beta$-adrenergic receptor or in the mechanism controlling the transmission of the hormonal stimulus.

In normal subjects, fasting plasma FFA levels and FFA mobilization seem to be positively correlated with the body fat mass or the cellularity of normally functioning adipose tissue $(46,47)$. In our patients, the insensitivity of lipomatous tissue to the catecholamine-induced lipolysis and the reduced amount of normal subcutaneous tissue could explain the decrease in FFA mobilization observed during fasting and after noradrenaline infusion.

The insensitivity of lipomatous tissue to the main stimuli regulating lipid mobilization could also explain the smaller decrease in fat cells observed in lipomatous tissue after body fat mass reduction.

It may be concluded that MSL develops as a result of zonal cellular proliferation. The neoformed cells show an anomalous metabolic behavior both in vivo and in vitro, characterized by insensitivity to the acute lipolytic action of catecholamines and to the long-acting physiological mechanisms regulating lipid mobilization in adipose tissue.

\section{ACKNOWLEDGMENTS}

This work was supported in part by Consiglio Nazionale delle Ricerche grant 74.005.05.4.

\section{REFERENCES}

1. Launois, P. E., and R. Bensaude. 1898. De l'adénolipomatose symétrique. Bull. Mem. Soc. Med. Hop. Paris. 1: $298-318$.

Multiple Symmetric Lipomatosis

1227 
2. Launois, P. E., and R. Bensaude. 1901. L'adenolipomatose symétrique à prédominance cervicale chez la femme. Bull. Mem. Soc. Med. Hop. Paris. 18: 675-682.

3. Clement-Coujard, G., and J. Truet. 1953. A propos de trois cas de maladie de Launois-Bensaude. Sem. Hop. Paris. 29: 409-417.

4. Deparis, M., A. Sarrazin, P. Auzépy, M. Robineau, and M. F. Forti. 1968. Cirrhose alcoolique et maladie de Launois-Bensaude. Étude histologique, clinique et pathogénique de la lipomatose symétrique diffuse à prédominance cervicale. Rev. Inter. Hepatol. 18: 799821.

5. Greene, M. L., C. J. Glueck, M. Y. Fujimoto, and J. E. Seegmiller. 1970. Benign symmetric lipomatosis (Launois-Bensaude adenolipomatosis) with gout and hyperlipoproteinemia. Am. J. Med. 48: 239-246.

6. Shammaua, D. 1955. Diffuse symmetrical lipomatosis of the face. J. Indian. Med. Assoc. 24: 263-264.

7. Madelung, O. W. 1888. Über den Fetthals. Arch. Klin. Chir. 37: 106. (Abstr.)

8. Hugenin, A., R. Gouric, and M. Brochier. 1952. Adénolipomatose symétrique de Launois-Bensaude. Alger. Med. 56: 375-381.

9. Chahrokhi, K. 1960. La lipomatose symétrique diffuse à predominance cervicale. Rev. Laryngol. Otol. Rhinol. 81: 551-568.

10. Taylor, L. M., O. H. Beahrs, and R. S. Fontana. 1961. Benign symmetric lipomatosis. Proc. Staff Meetings Mayo Clin. 36: 96-100.

11. Colomb, D., and B. Durang. 1967. Adénolipomatose symétrique de Launois-Bensaude spècialement intense. Bull. Soc. Fr. Dermatol. Syphiligr. 74: 400-401.

12. Mounier-Kuhn, P., and J. P. Haguenauer. 1967. Localization laryngée d'une maladie de Launois-Bensaude. $J$. Franc. Othorinolaryng. 16: 603.

13. Comings, D. E., and H. Glenchur. 1968. Benign symmetric lipomatosis. J. Am. Med. Assoc. 203: 305.

14. Hugo, N. E., and H. Conway. 1966. Benign symmetric lipomatosis: a case report. Plast. Reconstr. Surg. 37: 69-71.

15. Grivaux, M., M. Gentilini, J. Soulié, and P. Badoual. 1969. Adénolipomatose symétrique de Launois-Bensaude et trouble du métabolisme lipidique. Sem. Hop. Paris. 45: 1958-1966.

16. Cole, O. R., and S. W. Hartwell. 1969. Symmetric lipomas of the neck. Report of three cases. Cleve. Clin. Q. 36: 91-96.

17. Abaza, A., A. Paraf, J. Desechaliere, and M. Gregoire. 1950. Cirrhose pigmentaire et lipomatose. Bull. Mem. Soc. Med. Hop. Paris. 100: 367-373.

18. Heully, F., J. Laurent, M. A. Bigard, J. P. Gonand, and J. Gillot. 1969. Anomalies du métabolisme lipidique et glucidique au cours d'une lipomatose de Launois-Bensaude. Presse Med. 77: 2001-2002.

19. Springer, H. A., and J. S. Whitehause. 1972. LaunoisBensaude adenolipomatosis. Plast. Reconstr. Surg. 50: 291-294.

20. Colwell, J. A., and S. R. Cruz. 1972. Effects of resection of adipose tissue on the diabetes and hyperinsulinism of benign symmetrical lipomatosis. Diabetes. 21: 13-15.

21. Strange, D. A., and W. J. Fessel. 1968. Benign symmetric lipomatosis. J. Am. Med. Assoc. 204: 339-340.

22. Hales, C. N., and P. J. Randle. 1963. Immunoassay of insulin with insulin antibody precipitate. Biochem. J. 88: $137-146$.

23. Dole, V. P. 1956. A relation between nonesterified fatty acids in plasma and the metabolism of glucose. J. Clin. Invest. 35: 150-154.
24. Sjöström, L., P. Björntorp, and J. Vrana. 1971. Microscopic fat cell size measurements on frozen-cut adipose tissue in comparison with automatic determination of osmium-fixed fat cells. J. Lipid. Res. 12: 521-530.

25. Edwards, K. D., and H. M. White. 1962. The simple measurement of obesity. Clin. Sci. (Oxf.). 22: 347-352.

26. Noble, R. P. 1968. Electrophoretic separation of plasma lipoproteins on agarose gel. J. Lipid Res. 9: 697-700.

27. Fredrickson, D. S., and R. S. Lees. 1965. A system for phenotyping hyperlipoproteinemia. Circulation. 31: 321-326.

28. Korn, E. D. 1955. Clearing factor and heparin activated lipoprotein lipase. Isolation and characterization of the enzyme from normal rat heart. J. Biol. Chem. 215: $1-14$.

29. Bihler, J., and B. Jeanrenaud. 1970. ATP content of isolated fat cells. Effects of insulin, ouabaine, and lipolytic agents. Biochim. Biophys. Acta. 202: 496-506.

30. Strehler, B. L., and J. R. Trotter. 1952. Firefly luminescence in the study of energy transfer mechanism. I. Substrate and enzyme determination. Arch. Biochem. Biophys. 40: 28-41.

31. Strehler, B. L., and J. R. Trotter. 1954. Determination of adenosine triphosphate and related compounds: firefly luminescence and other methods. In Methods Biochem. Analysis. D. Glick, editor. Interscience Pubs., Inc., New York. 1502-1522.

32. Kodish, M. E., R. N. Alsever, and M. B. Block. 1974. Benign symmetric lipomatosis: functional sympathetic denervation of adipose tissue and possible hypertrophy of brown fat. Metab. Clin. Exp. 23: 937-945.

33. Hirsh, J., and B. Batchelor. 1976. Adipose tissue cellularity in human obesity. In Clinics in Endocrinology and Metabolism. M. J. Albrink, editor. W. B. Saunders Company, Div. of CBS, Inc. Philadelphia. 299-311.

34. Hauxberger, F. X. 1964. Neurogenic factors affecting adipose tissue metabolism. In Fat as a Tissue. K. Rodahl and B. Issekutz, editors. McGraw-Hill, New York. 239249.

35. Björntorp, P. 1964. The fatty acid release and lipolysis of human subcutaneous adipose tissue in vitro. Metab. Clin. Exp. 13: 1318-1326.

36. Mosinger, B., E. Kuhn, and V. Kujalova. 1965. Action of adipokinetic hormones on human adipose tissue in vitro. J. Lab. Clin. Med. 66: 380-389.

37. Björntorp, P. 1967. Lipid mobilization from human subcutaneous adipose tissue in vitro. Acta Med. Scand. 182 : 717-726.

38. Jeanrenaud, B. 1968. Adipose tissue, dynamic and regulation. Ergeb. Physiol. Biol. Chem. Exp. Pharmakol. 60: 57-140.

39. Carlson, L. A., D. Hallberg, and H. Micheli. 1969. Quantitative studies on the lipolytic response of human subcutaneous and omental adipose tissue to noradrenaline and theophylline. Acta Med. Scand. 185 465-469.

40. Östman, J., and S. Efendic. 1969. Alpha-adrenergic receptors in human omentum. Lancet. I: 202. (Abstr.)

41. Efendic, S. 1970. Catecholamines and metabolism of human adipose tissue. III. Comparison between the regulation of lipolysis in omental and subcutaneous adipose tissue. Acta Med. Scand. 187: 477-483.

42. Wenke, M. 1970. Adrenotropic drugs in lipid mobilization. In Adipose tissue. Regulation and Metabolic Functions. B. Jeanrenaud and D. Hepp, editors. G. Thieme Verlag Academic Press, Inc., New York. 55-62. 
43. Fain, J. N. 1973. Biochemical aspects of drug and hormone action on adipose tissue. Pharmacol. Rev. 25: 67-118.

44. Fassina, G., P. Dorigo, and R. M. Gaion. 1975. Hormoneinduced lipolysis and the metabolic pathways providing energy to the cell: a possible role of ATP as a rate limiting factor. Ad. Exp. Med. Biol. 63: 105-122.

45. Fassina, G., P. Dorigo, and R. M. Gaion. 1976. Metabolic pathways in adipose tissue and their physiopathological significance in relation to atherosclerosis. In Methods in
Atherosclerosis Research. D. Kritchevsky and R. Paoletti, editors, Plenum Publishing Corp., New York. In press.

46. Stern, M. P., J. Olefsky, J. W. Farquar, and G. M. Reaven. 1973. Relationship between fasting plasma lipid levels and adipose tissue morphology. Metab. Clin. Exp. 22: 1.311-1317.

47. Goldrick, R. B., and G. M. McLoughlin. 1970. Lipolysis and lipogenesis from glucose in human fat cells of different size. Effect of insulin, epinephrine and theophylline. J. Clin. Invest. 49: 1213-1223. 